\title{
FRESHWATER HEADS AND GROUND-WATER TEMPERATURES IN AQUIFERS OF THE NORTHERN GREAT PLAINS IN PARTS OF MONTANA, NORTH DAKOTA, SOUTH DAKOTA, AND WYOMING
}

\section{RHGIONAI AQUTFER-SYSTEM ANALYSIS}

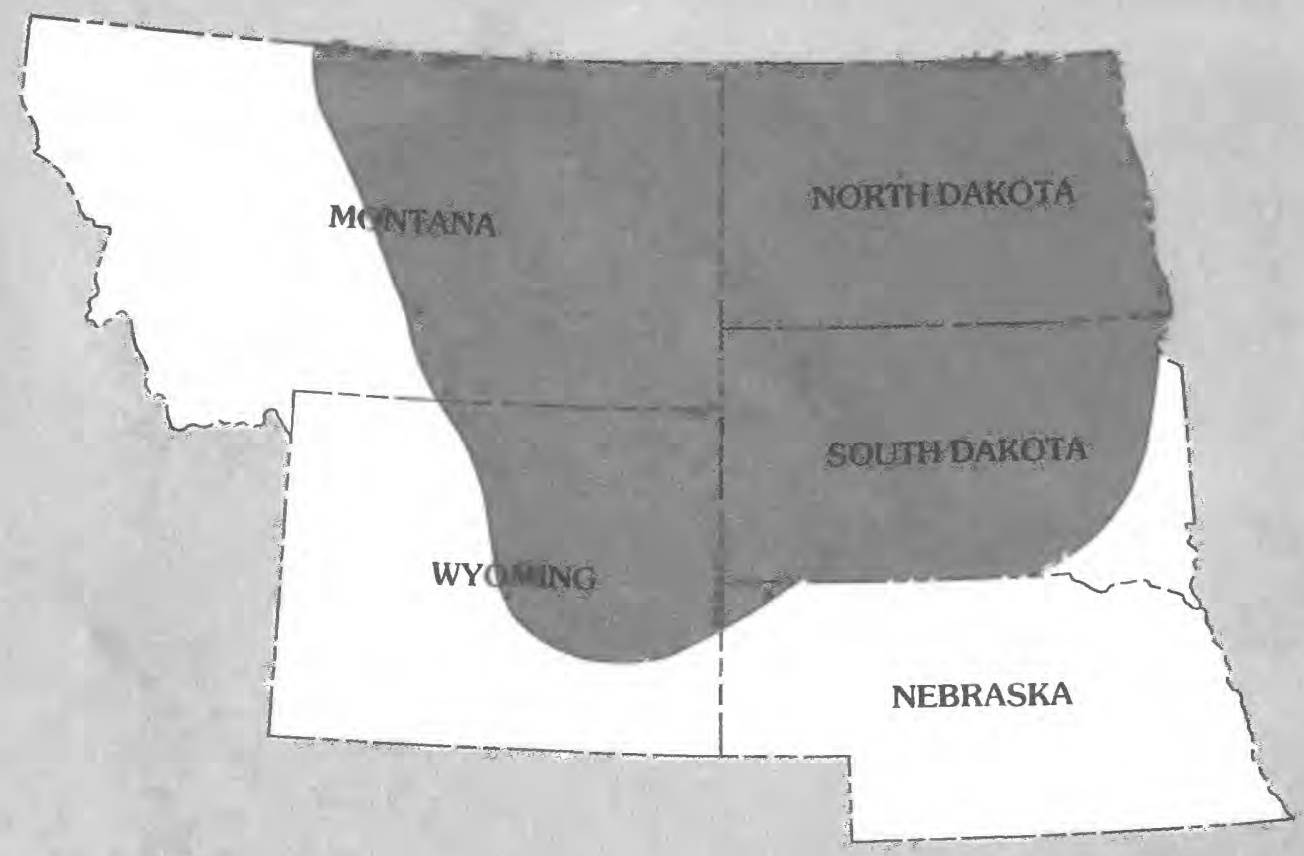




\section{Freshwater Heads and Ground-Water}

Temperatures in Aquifers of the Northern Great Plains in parts of Montana, North Dakota, South Dakota, and Wyoming

By DAVID H. LOBMEYER

REGIONAL AQUIFER-SYSTEM ANALYSIS

U.S. GEOLOGICAL SURVEY PROFESSIONAL PAPER 1402-D

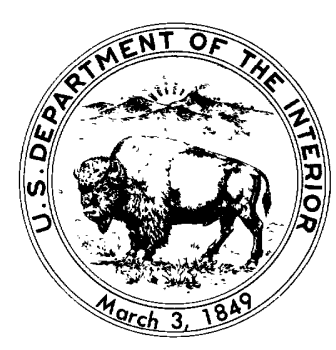

\begin{tabular}{lllllll}
\hline UNITED & STATES & GOVERNMENT & PRINTING & OFFICE, & WASHINGTON & $:$ \\
\hline
\end{tabular} 


\title{
UNITED STATES DEPARTMENT OF THE INTERIOR
}

\author{
WILLIAM P. CLARK, Secretary
}

\section{GEOLOGICAL SURVEY}

Dallas L. Peck, Director

Lobmeyer, David H.

Freshwater heads and ground-water temperatures in aquifers of the Northern Great Plains in parts of Montana, North Dakota, South Dakota, and Wyoming.

(Northern Great Plains RASA project) (Geological Survey professional paper; 1402-D) Bibliography: p. 11

Supt. of Docs. no.: I 19.16:1402-D

1. Aquifers-Great Plains. 2. Water, Underground-Great Plains-Temperature. 3. Potentiometric. 4. Groundwater flow-Great Plains. I. Title. II. Series, III. Series: Geological Survey professional paper; 1402-D

For sale by the Branch of Distribution

U.S. Geological Survey

604 South Pickett Street

Alexandria, VA 22304 


\section{FOREWORD}

\section{THE REGIONAL AQUIFER-SYSTEM ANALYSIS PROGRAM}

The Regional Aquifer-System Analysis (RASA) Program was started in 1978 following a congressional mandate to develop quantitative appraisals of the major ground-water systems of the United States. The RASA Program represents a systematic effort to study a number of the Nation's most important aquifer systems, which in aggregate underlie much of the country and which represent an important component of the Nation's total water supply. In general, the boundaries of these studies are identified by the hydrologic extent of each system, and accordingly transcend the political subdivisions to which investigations have often arbitrarily been limited in the past. The broad objective for each study is to assernbly geologic, hydrologic, and geochemical information, to analyze and develop an understanding of the system, and to develop predictive capabilities that will contribute to the effective management of the system. The use of computer simulation is an important element of the RASA studies, both to develop an understanding of the natural, undisturbed, hydrologic system, and the changes brought about in it by human activities, and to provide a means of predicting the regional effects of future pumping or other stresses.

The final interpretive results of the RASA Program are presented in a series of U.S. Geological Survey Professional Papers that describe the geology, hydrology, and geochemistry of each regional aquifer system. Each study within the RASA Program is assigned a single Professional Paper number, and where the volume of interpretive material warrants, separate topical chapters that consider the principal elements of the investigation may be published. The series of RASA interpretive reports begins with Professional Paper 1400 and thereafter will continue in numerical sequence as the interpretive products of subsequent studies become available.

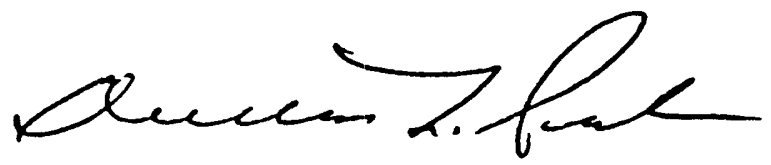

Dallas L. Peck Director 



\section{CONTENTS}

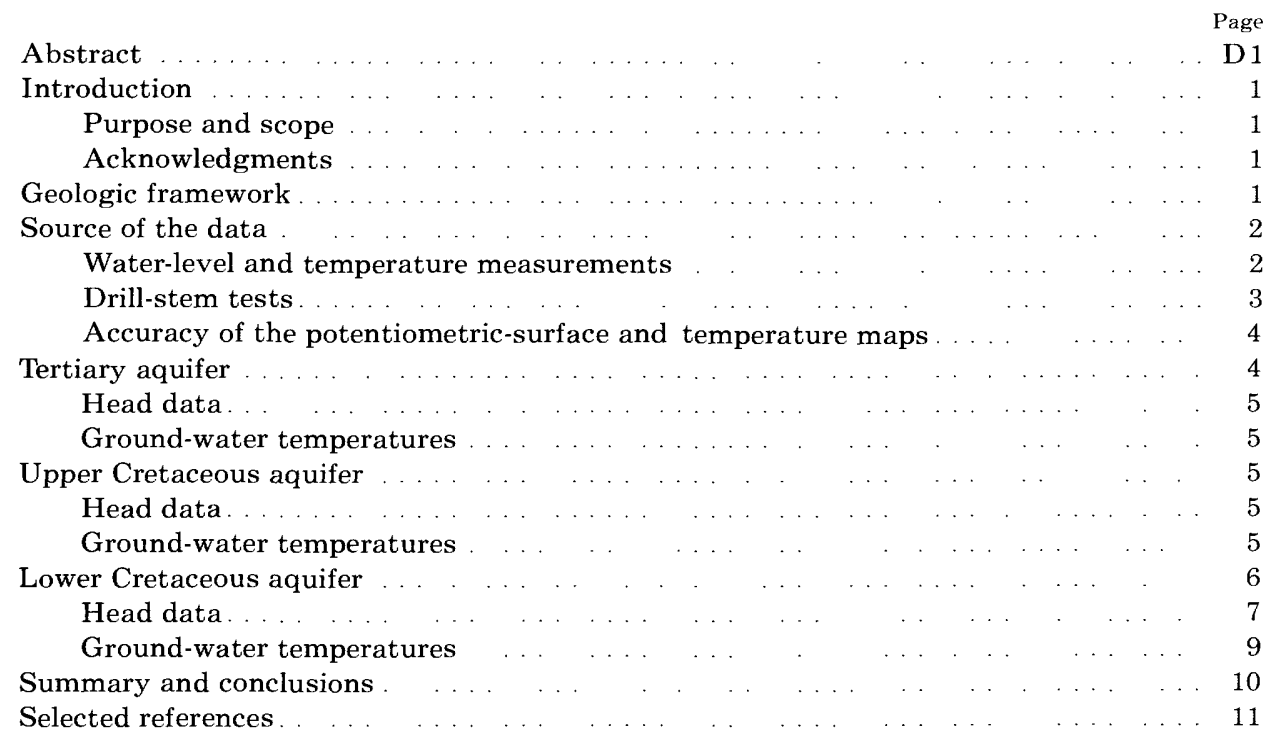

\section{ILLUSTRATIONS}

Plate 1. Correlation chart of Jurassic, Cretaceous, and Tertiary rocks of the Northern Great Plains

Page In pocket

FIGURE 1. Index map showing location of Northern Great Plains study area $\ldots \ldots \ldots \ldots \ldots$ 2-7. Maps showing:

2. Present structural and physiographic features in and near the study area $\ldots \ldots \ldots \ldots \ldots$

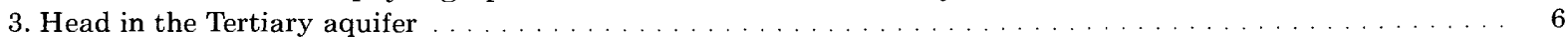

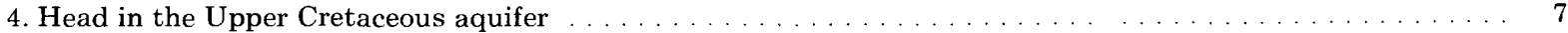

5. Water temperatures in the Upper Cretaceous aquifer $\ldots \ldots \ldots \ldots \ldots \ldots \ldots \ldots \ldots \ldots$

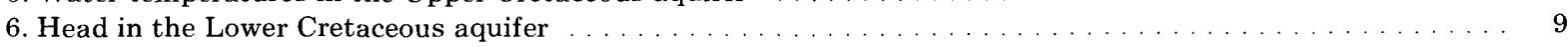

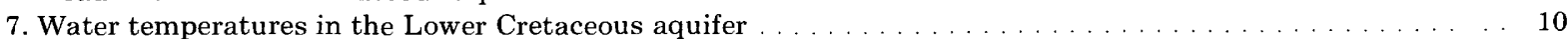




\section{GLOSSARY}

Aquifer: A formation, group of formations, or part of a formation that contains sufficient saturated permeable material to yield significant quantities of water to wells and springs.

Head, static, $h[L]$ : The height above a standard datum of the surface of a column of water (or other liquid) that can be supported by the static pressure at a given point; potentiometric surface or head, used alone, is understood to mean static head.

Confining bed: A body of relatively impermeable material stratigraphically adjacent to one or more aquifers. Hydraulic conductivity of a confining bed is distinctly less than that of the aquifer.

NGVD of 1929: National Geodetic Vertical Datum of 1929, commonly referred to as mean sea level.

Potentiometric surface: A surface that represents the static head; related to an aquifer, it is defined by the levels to which water will rise in tightly cased wells. When the head varies appreciably with depth in the aquifer, a potentiometric surface is meaningful only if it describes the static head along a particular specified surface or stratum in that aquifer. More than one potentiometric surface then is required to describe the distribution of head in the aquifer in which head varies with depth. The water table is the potentiometric surface at the top of an unconfined aquifer.

Transmissivity, $T\left[L^{2} T^{-1}\right]$ : The rate at which water of the prevailing kinematic viscosity is transmitted through a unit width of the aquifer under a unit hydraulic gradient; as a property of the aquifer, it also embodies the saturated thickness of the aquifer and the properties of the contained liquid.

Viscosity: The internal fluid friction to which a fluid resists flow under an applied pressure.

\section{CONVERSION FACTORS}

Factors for converting inch-pound units to metric units are shown in the following table:

\begin{tabular}{lcl}
\hline \multicolumn{1}{c}{ Inch-pound } & Multiply by & \multicolumn{1}{c}{ Metric } \\
\hline foot $(\mathrm{ft})$ & 0.3048 & meter $(\mathrm{m})$ \\
square mile $\left(\mathrm{mi}^{2}\right)$ & 2.590 & square $\mathrm{kilometer}\left(\mathrm{km}^{2}\right)$ \\
pound per square inch $\left(\mathrm{lb} / \mathrm{in}^{2}\right)$ & 6.8948 & kilopascal $(\mathrm{kPa})$ \\
mile $(\mathrm{mi})$ & 1.609 & kilometer $(\mathrm{km})$ \\
& & \\
The temperature in degree Celsius $\left({ }^{\circ} \mathrm{C}\right)$ can be converted to temperature in degree Fahrenheit \\
$\left({ }^{\circ} \mathrm{F}\right)$ using the following equation: \\
\end{tabular}




\title{
FRESHWATER HEADS AND GROUND-WATER TEMPERATURES IN AQUIFERS OF THE NORTHERN GREAT PLAINS IN PARTS OF MONTANA, NORTH DAKOTA, SOUTH DAKOTA, AND WYOMING
}

\author{
By David H. Lobmeyer
}

\begin{abstract}
Potentiometric surfaces of the Tertiary aquifer, the Upper Cretaceous aquifer, and the Lower Cretaceous aquifer in the Northern Great Plains of Montana, North Dakota, South Dakota, and Wyoming generally follow land-surface gradients except in areas where geologic structure or lithologic change cause large differences in transmissivity, flow path, or both. Ground-water temperatures generally are controlled by the burial depth of the aquifer.

Actual-equilibrium water temperatures are estimated to range from about $7^{\circ}$ to about $174^{\circ}$ Celsius. No areally extensive temperature anomalies were detected. Water temperatures in the Upper Cretaceous and Lower Cretaceous aquifers were mapped and were used to correct aquifer transmissivities calculated from laboratory permeabilities for modeling the regional-aquifer systems.
\end{abstract}

\section{INTRODUCTION}

\section{PUR POSE AND SCOPE}

Ground water is a relatively unused resource in the Northern Great Plains of Montana, North Dakota, South Dakota, and Wyoming. However, there have been some large withdrawals of water from the Dakota Sandstone in the eastern part of the area. The purpose of this study was to map potentiometric surfaces for the Tertiary, Upper Cretaceous, and Lower Cretaceous aquifers as part of a digital-simulation study of the occurrence of ground water in the eastern part of Montana, a small part of northwestern Nebraska, all of North Dakota, all except extreme southeastern South Dakota, and the northeastern part of Wyoming (fig. 1).

Water temperatures in formations that range in depth from land surface to as much as $15,000 \mathrm{ft}$ might range from about $7^{\circ}$ to about $174^{\circ} \mathrm{C}$, assuming a geothermal gradient of $1^{\circ} \mathrm{C}$ per $90 \mathrm{ft}$ of depth. As this temperature difference causes large variations in density and viscosity of water, it may be necessary to make temperature corrections of hydrologic properties determined for the formations. These corrections are especially important when aquifer characteristics determined at shallow depths are extended to deeper parts of the aquifers. Temperature variations in the Upper Cretaceous aquifer and the Lower Cretaceous aquifer are believed to be large enough to warrant mapping the temperatures for use in correcting heads for density and aquifer transmissivities for viscosity.

\section{ACKNOWLEDGMENTS}

Numerous U.S. Geological Survey personnel helped with data selection and map compilation. Raymond D. Butler compiled a head map for the Lower Cretaceous aquifer in North Dakota, selected the formations in the Upper Cretaceous aquifer for study, and advised on accuracy of some data for water temperatures in the Lower Cretaceous aquifer. H. Lee Case compiled a head map for the Lower Cretaceous aquifer in central and eastern South Dakota. William R. Hotchkiss compiled a head map for the Tertiary aquifer in the Powder River basin, Montana and Wyoming. Dwight T. Hoxie selected drill-stem test data that were used to define the potentiometric surface for the Lower Cretaceous aquifer throughout the study area where no other water-level data were available. Gary W. Levings selected drill-stem test data for the Tertiary and Lower Cretaceous aquifers in Montana and mapped heads for part of eastern Montana. Marlin E. Lowry provided data from recently drilled wells in the Powder River basin, Wyoming.

\section{GEOLOGIC FRAMEWORK}

The aquifers discussed in this report comprise only a small part of the geologic section in the Northern Great Plains (pl. 1). The aquifers were selected for continuity throughout the area. The Tertiary aquifer includes the Wasatch Formation and the Fort Union Formation and equivalent rocks. The Upper Cretaceous aquifer consists of the lower part of the Hell Creek Formation and the Fox Hills Sandstone. The upper part of the Hell Creek Formation is a confining layer. All formations between the top of the Pierre Shale and the base of the Mowry Shale are regarded as a confining layer. The Lower Cretaceous aquifer consists of the formations between the top of the Muddy Sandstone or the Newcastle Sandstone and the base of the Kootenai Formation or Lakota Formation, or equivalents, for purposes of the digital model of the regional-aquifer system. 


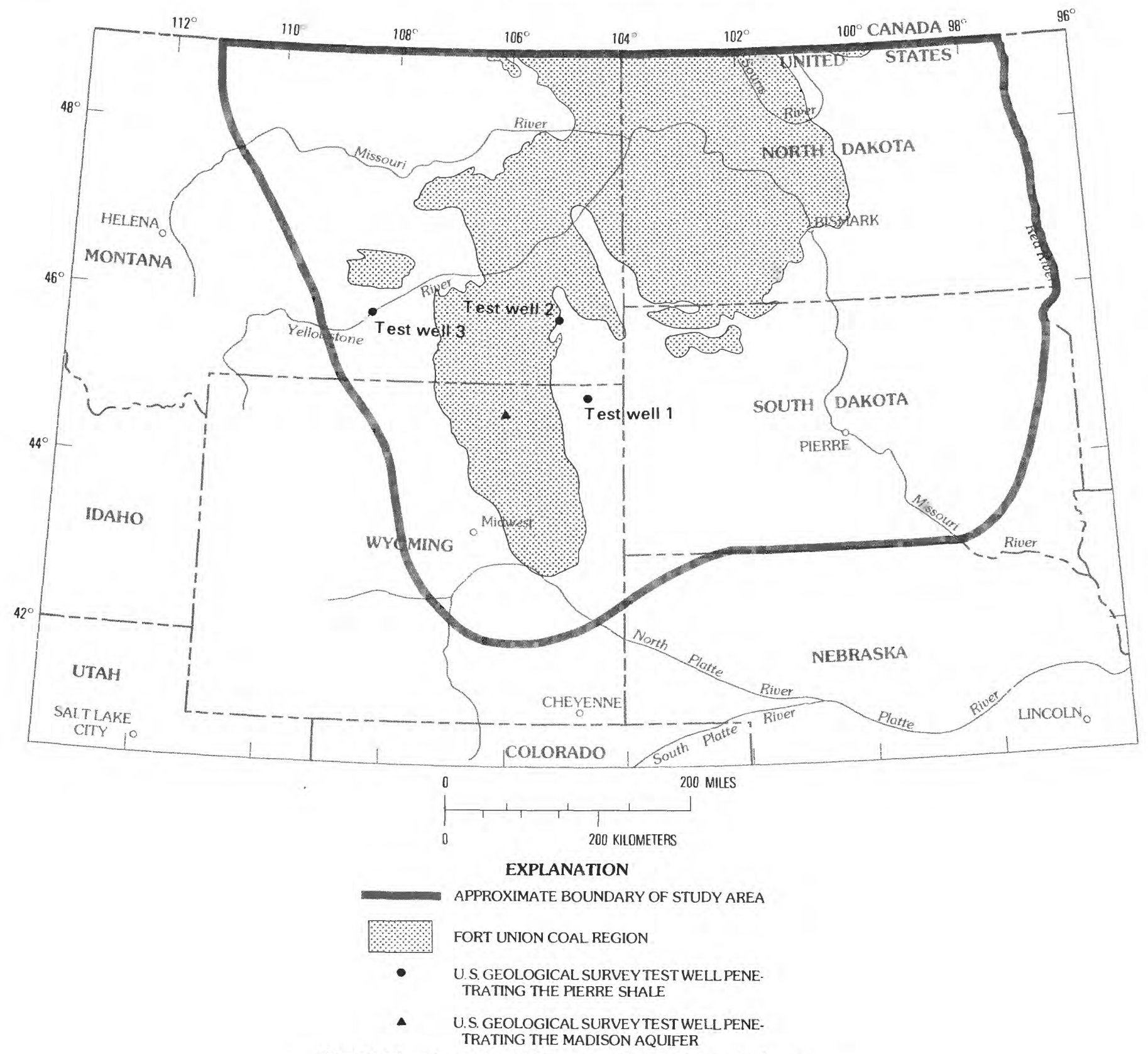

FrGURE 1.-Location of Northern Great Plains study area.

\section{SOURCE OF THE DATA}

\section{WATER-LEVEL AND TEMPERATURE MEASUREMENTS}

Water-level measurements and ground-water temperatures are available in or near outcrop areas where aquifers are used for domestic, stock, and municipal water supplies. The Tertiary aquifer generally is close enough to the land surface that water-level measurements are available; however, the water levels are only for the upper part of the aquifer where the water-yielding material is thick enough to provide a domestic supply. The Upper
Cretaceous aquifer is near enough to the land surface that it is used for domestic and municipal supplies except in the deeper parts of the structural basins (fig. 2). In the deepest part of the Powder River basin, the basal sandstone of the Upper Cretaceous aquifer may be as much as $7,500 \mathrm{ft}$ below the surface, and in the Williston basin it is about 2,700 ft below land surface. Most of the Lower Cretaceous aquifer is deeper than the depth of domestic or stock wells, except in the eastern part of North Dakota and South Dakota; and much of the aquifer contains water with excessive dissolved-solids concentrations that makes it unsuitable for most purposes. 


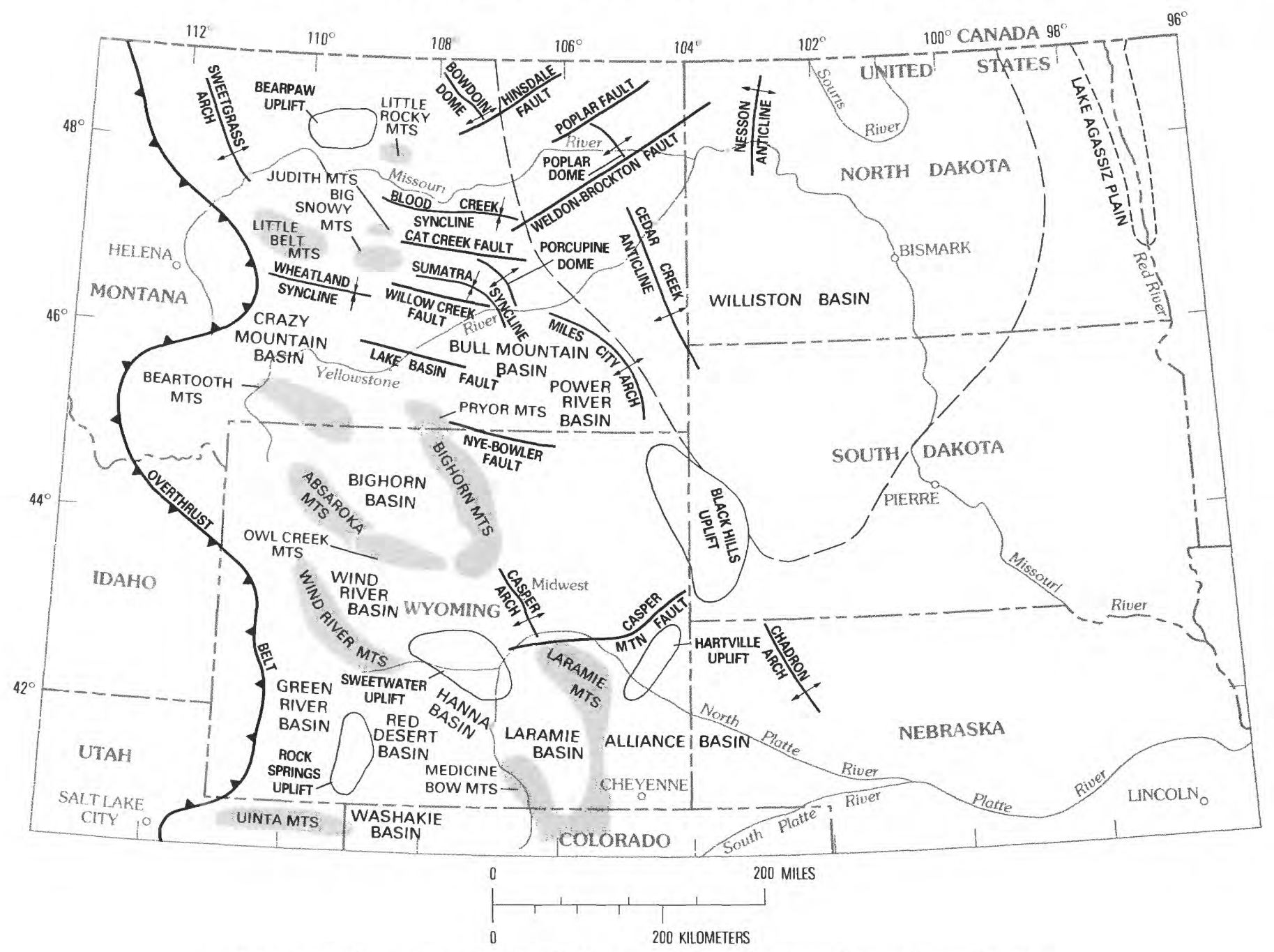

FIGURE 2.-Present structural and physiographic features in and near the study area.

\section{DRILLSTEM TESTS}

Where the aquifers are deeper than the depth of domestic, stock, and municipal wells, data from oil-field drill-stem tests were used to estimate the heads. Bottomhole temperatures, often measured during drill-stem tests, were used to estimate water temperatures.

Drill-stem tests were selected for analysis if the shutin time was at least twice as long as the flow period and an appreciable amount of fluid, other than drilling fluid, was produced. The final shut-in pressure was converted to equivalent freshwater head according to the procedure outlined by Miller (1976, p. 17). The following equation was used:

$$
h=(F S I P \times C)-P R D+L S D,
$$

where

$h$ is the altitude of the water surface, in feet above NGVD (1929);
FSIP is the final bottom-hole shut-in pressure, in pounds per square inch, measured by the pressurerecording device;

$C$ is a factor to convert FSIP to equivalent feet of water;

$P R D$ is the depth to the pressure-recording device, in feet below $L S D$; and

$L S D$ is the land-surface datum, in feet above NGVD (1929).

A factor $C$ of $2.307 \mathrm{ft}$ of water per pressure increment of $1 \mathrm{lb} / \mathrm{in}^{2}$ was used. This value assumes the water is pure water at temperature of $4.0^{\circ} \mathrm{C}$ with a density of 1.0 gram per cubic centimeter. Maps compiled using this factor then can be used with water temperature, density, and viscosity data in digital models of the flow system.

To determine the altitude to which formation water would actually rise in a tightly cased well, the pressure heads were corrected for density variations resulting 
from variation in temperature and dissolved-solids concentration. Equation 1 was modified to reflect density corrections as:

$$
h=(2.307+C t-C s) F S I P-P R D+L S D,
$$

where

$C t$ is the temperature correction; and

$C s$ is the dissolved-solids correction.

The temperature correction, $C t$, is positive and can be calculated from temperature-density table of water. For example, at $10^{\circ} \mathrm{C}$, water density is 62.40986 pounds per cubic foot, which is $2.30733 \mathrm{ft} /\left(\mathrm{lb} / \mathrm{in}^{2}\right.$ ) (feet per pound per square inch). Therefore, $C t$ is 0.00033 .

The dissolved-solids correction, $\mathrm{Cs}$, is negative, and is $0.007 \mathrm{ft} /\left(\mathrm{lb} / \mathrm{in}^{2}\right.$ ) for each $5,000 \mathrm{mg} / \mathrm{L}$ (milligrams per liter) change in dissolved-solids concentration if sodium and chloride are the major constituents.

The net result of correcting the data for the density would be maps similar to those in this report, except that the heads in the Lower Cretaceous aquifer might be as much as $500 \mathrm{ft}$ higher in the deepest part of the Powder River basin in northeastern Wyoming; water-level altitudes on such maps would show the actual height that freshwater would stand in an open hole and would indicate the true horizontal hydraulic gradient.

Several drill-stem tests with associated bottom-hole temperatures along the eastern edge of the Powder River basin were compared. In most instances, temperatures and pressures varied greatly within a few square miles. Low temperatures and low heads were always associated with low fluid recoveries. High heads and high temperatures usually were associated with high fluid recoveries. The largest head values seemed to be along structural trends that may have controlled sand deposition and, therefore, locally increase in porosity, according to Slack (1981).

High fluid recoveries probably indicate that the test holes may have better connection with the formation than the test holes yielding low fluid recoveries; therefore, it is believed that the temperatures and heads determined from drill-stem tests made in test holes that yielded high fluid recoveries probably are closer to the actual formation temperatures and heads than those determined from drill-stem tests made in test holes that yielded low fluid recoveries.

\section{ACCURACY OF THE POTENTIOMETRIC-SURFACE AND TEMPERATURE MAPS}

Accuracy of the recording devices used in drill-stem tests was reported to be from 0.20 to 0.25 percent of the full scale (Earlougher, 1977). Thus, the individual mea- surements in the deepest part of the Powder River basin might be as much as $10 \mathrm{ft}$ above or below the actual values. Comparison of pressures from drill-stem tests and known water levels in a test well (Lobmeyer and others, 1982) indicate that accuracy of heads converted from pressure readings might be closer to 2 percent of the total head or $\pm 100 \mathrm{ft}$. Additionally, most head values measured by pressure probably are not static heads because of relatively short shut-in times. The water in the well has not recovered to the undisturbed formation head after drilling. Bottom-hole temperatures measured at the same time as the pressures have similar problems. The temperature values measured in a well are not in equilibrium with the formation temperatures, because the temperature measures were taken shortly after the end of drilling-fluid circulation. The temperature reading might be almost any value between the temperature of the drilling fluid and the actual formation temperature, depending on elapsed time and volume and type of fluid produced during the test.

On the basis of data distribution and reliability, the accuracy of head maps made for the Tertiary and Upper Cretaceous aquifers is believed to be within one contour interval ( $200 \mathrm{ft}$ ) except where the contours were inferred from surface altitudes that were obtained from a $1: 1,000,000$ topographic contour map with a contour interval that varied according to local relief. Accuracy of the head maps of the Lower Cretaceous is believed to be within one-half contour interval in eastern North Dakota and eastern South Dakota ( $100 \mathrm{ft}$ ), and within one contour interval $(200 \mathrm{ft}$ ) for the other areas where the contours are widely spaced. In the areas around the Black Hills on the South Dakota-Wyoming border, around the edge of the Powder River basin, and in central Montana, the accuracy of the head map probably is only $500 \mathrm{ft}$. The temperature maps are believed to be accurate within one-half contour interval $\left(5^{\circ} \mathrm{C}\right.$ for the Upper Cretaceous aquifer map and $10^{\circ} \mathrm{C}$ for the Lower Cretaceous aquifer map).

\section{TERTIARY AQUIFER}

The uppermost aquifer, except for local alluvial aquifers in stream valleys and aquifers in glacial deposits mostly north and east of the Missouri River, is the Tertiary aquifer. Most of the measurements of water levels in the Tertiary aquifer were made in wells completed in the Wasatch Formation in Wyoming, and in the Fort Union Formation in the remainder of the area. As most wells were drilled no deeper than necessary to obtain a freshwater supply, water-level and temperature measurements for the Tertiary aquifer are generally from wells completed in the upper part of the aquifer. 


\section{HEAD DATA}

Head data available for the area were contoured by various techniques on a map scale of 1:2,500,000. Data for the Powder River basin including the part of the area south of the Yellowstone River were processed and contoured by kriging described by Skrivan and Karlinger (1980). Data for the remainder of the area were contoured with a computer program that averaged the data throughout an area equal to about a 60 - by 60 -mi square. Areas covered by glacial deposits have very few water-level measurements in the Tertiary aquifer, and the water levels were inferred from surface-water levels and publications from adjacent areas (Whitaker, 1970, 1974a, and 1974b).

Water levels in the Tertiary aquifer (fig. 3 ) in general follow land-surface contours, indicating that the topographically high areas generally are recharge areas and that the valleys generally are discharge areas. Lowry (1981) observed that much of the water discharged in valleys may evaporate or be transpired by vegetation. A broad ground-water divide coinciding with a persistent structural arch of low relief (Slack, 1981), is present south of the Belle Fourche River basin. In the southern part of the Powder River structural basin, the potentiometric surface indicates ground-water movement to the southeast. This part of the Powder River structural basin has no perennial streams and is the only part of the study area where ground-water gradients are not similar to stream slopes.

Major recharge areas appear to be in the topographically high areas in the Powder River structural basin, in east-central Montana, and in western North Dakota. The major discharge area seems to be along the Missouri River and along the Yellowstone and Powder Rivers.

\section{GROUND-WATER TEMPERATURES}

The shallow depth of the Tertiary aquifer means that water temperatures in the aquifer generally reflect the annual mean air temperature, which is estimated to be around $7^{\circ} \mathrm{C}$; therefore, ground-water temperatures in the Tertiary aquifer were not mapped.

\section{UPPER CRETACEOUS AQUIFER}

The major part of the Upper Cretaceous aquifer is the widespread Fox Hills Sandstone, probably the most continuous water-bearing strata in the study area. Numerous studies of the Fox Hills Sandstone have been made; considerable data are available throughout the area where the aquifer is used for water supplies. Data from oil-field, drill-stem tests for the aquifer are not common.

\section{HEAD DATA}

Calculated values of equivalent freshwater head and freshwater head directly measured in the Upper Cretaceous aquifer permitted the author to contour the potentiometric surface. Contours in outcrop areas where data are lacking were inferred from surface-water levels.

The potentiometric surface of the Upper Cretaceous aquifer (fig. 4) shows the same general pattern as the potentiometric surface of the Tertiary aquifer. Because the horizontal permeability of the $6,000 \mathrm{ft}$ Upper Cretaceous aquifer is much greater than its vertical permeability, it is believed that the flow in the Upper Cretaceous aquifer is probably horizontal, except in outcrop areas, rather than having significant vertical components of flow near stream valleys as indicated in the Tertiary aquifer. The water levels in the Tertiary aquifer and the Upper Cretaceous aquifer may differ by as much as $200 \mathrm{ft}$ in northeastern Wyoming near the center of the Powder River structural basin, which probably indicates that water moves downward into the Upper Cretaceous aquifer. Flow in the Powder River structural basin generally is to the north except in the southeastern part where flow is to the southeast. In the Williston basin, the flow generally is to the east except locally along stream valleys.

Heads generally are highest along the southern and western limit of the aquifer, indicating probable recharge areas. Several topographic highs in north-central Montana are underlain by potentiometric highs, indicating recharge in those areas also. Discharge from the aquifer is indicated along the stream valleys in the eastern part of the Powder River structural basin and along the Yellowstone and Missouri Rivers. In central North Dakota, water in the aquifer appears to be flowing toward and discharging into the Missouri River from both east and west.

\section{GROUND-WATER TEMPERATURES}

Data for water temperatures in the Upper Cretaceous aquifer were processed with a computer program that selected the highest temperature within each 4-mi square, and these values then were averaged within a $20-\mathrm{mi}$ radius. The contoured map using those data is weighted toward the temperature of water in the basal part of the aquifer, the Fox Hills Sandstone.

The high water temperatures (fig. 5) in the Powder River and Williston basins coincide with the deepest parts of those basins. The highest temperature in the Powder River structural basin $\left(66^{\circ} \mathrm{C}\right)$ is where the depth to the base of the Fox Hills Sandstone is about 7,500 ft below land surface. The geothermal gradient calculated for the Powder River basin at the depth is $1^{\circ} \mathrm{C}$ per $126 \mathrm{ft}$ of depth. This geothermal gradient is unusual. The closed 


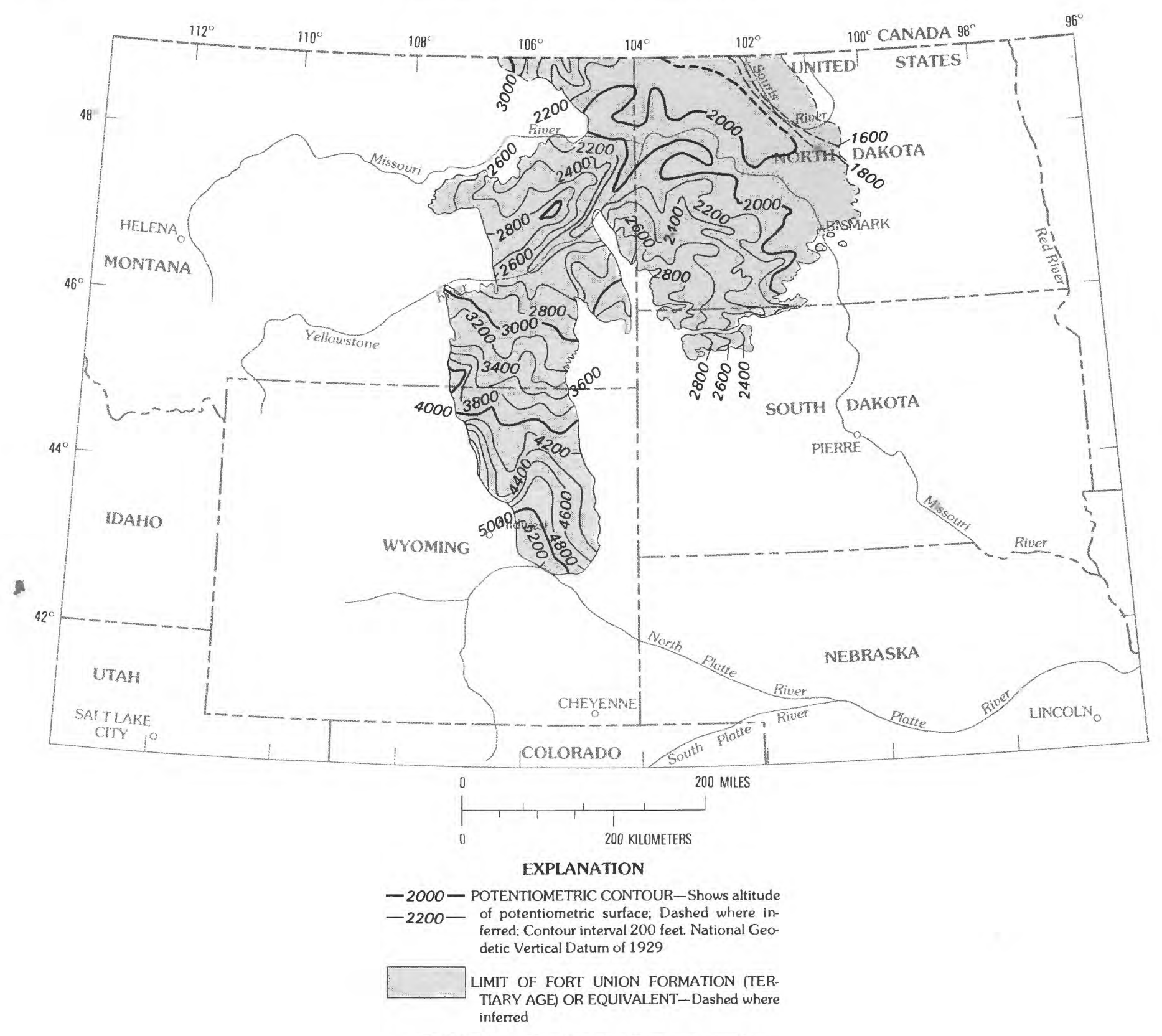

FIGURE 3.- Head in the Tertiary aquifer.

$40^{\circ} \mathrm{C}$ line in the Williston basin in North Dakota (fig. 5) coincides with a depth to the base of the aquifer of about $2,700 \mathrm{ft}$, giving a geothermal gradient of $1^{\circ} \mathrm{C}$ per $90 \mathrm{ft}$ of depth. This geothermal gradient probably is more reasonable in the study area.

Lowest ground-water temperatures (generally less than $10^{\circ} \mathrm{C}$ ) are in the discharge area in central North Dakota and are related to the shallow depth of the aquifer.

\section{LOWER CRETACEOUS AQUIFER}

The water-bearing parts of the Lower Cretaceous aquifer are a complex of discontinuous sand bodies that are separated by siltstone and shale in the western part of the area. These beds of sandstone merge into a more or less continuous aquifer in eastern North Dakota and eastern South Dakota. The location of sand bodies 


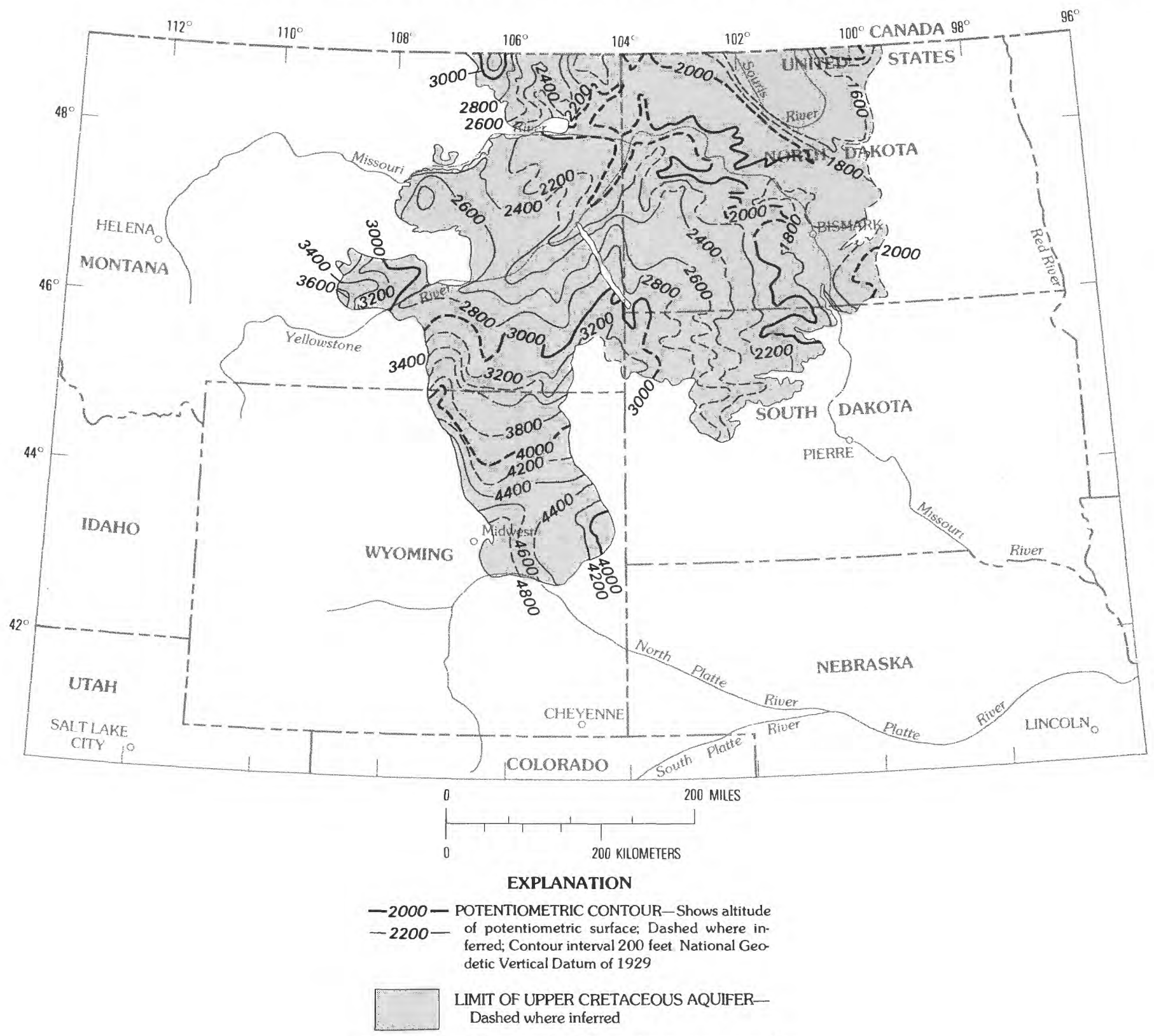

FIGURE 4.-Head in the Upper Cretaceous aquifer.

appears to be governed by minor structures where sand was deposited downgradient from areas of slightly greater relief (Slack, 1981).

\section{HEAD DATA}

Data from drill-stem tests were averaged over a radius of $8 \mathrm{mi}$, moving in a south-to-north and west-to-east direction, in a band about $16 \mathrm{mi}$ wide. If several tests were conducted in the same drill hole, the heads from these were averaged first. Some of the 16-mi-diameter circles contained as many as 125 values in and around producing oil fields.

The potentiometric surface of the Lower Cretaceous aquifer (fig. 6) is significantly different from the potentiometric surfaces of the Upper Cretaceous and Tertiary aquifers, whereas potentiometric surfaces of the Tertiary and Upper Cretaceous aquifers are similar to topography, which generally is not controlled by geologic structures. The potentiometric surface in the Lower Cretaceous 


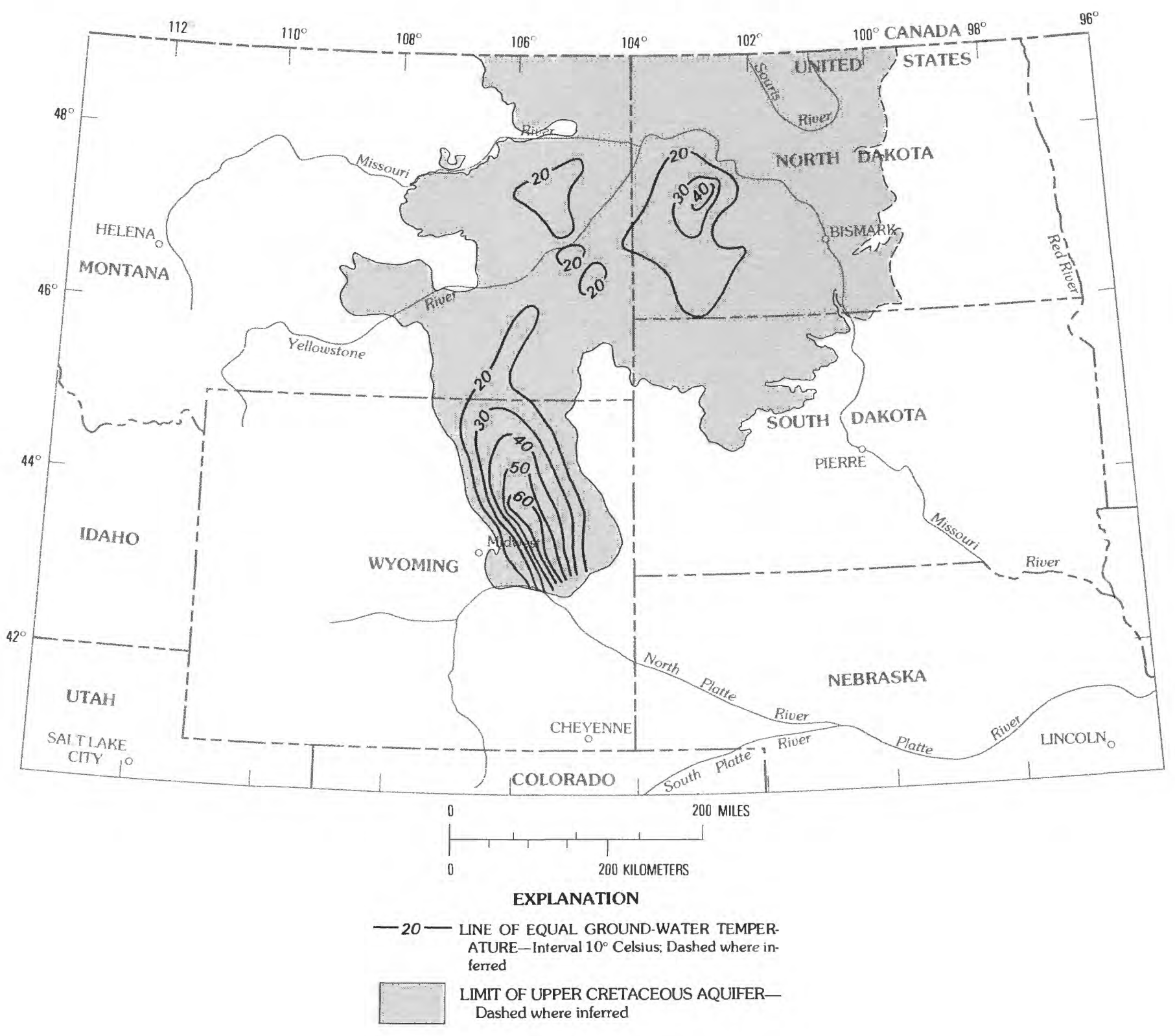

FIGURE 5. - Water temperatures in the Upper Cretaceous aquifer.

aquifer, which is separated from the land surface by as much as $10,000 \mathrm{ft}$ of sedimentary rocks, appears to be significantly affected by geologic structures. Most of the local relief in the southern Powder River structural basin may be related to the distribution of elongated sand bodies, whose locations are controlled by persistent easttrending features (Slack, 1981). In general, the hydraulic gradient is much less and several features, such as potentiometric-surface depressions in the Powder River and Williston basins, are absent in the Tertiary and Upper Cretaceous aquifers.

Recharge to the Lower Cretaceous aquifer is at the edges of small basins in central Montana, at the western edge of the Powder River basin, and at the edge of the Black Hills uplift. In south-central North Dakota and across central South Dakota, the Lower Cretaceous aquifer appears to be receiving water from the underlying Paleozoic rocks.

Natural discharge from the aquifer takes place where streams cross the outcrop areasin Montana and Wyoming and by leakage through overlying sediments in eastern North Dakota and South Dakota. The deep depression shown by the potentiometric surface (fig. 6) in the northern part of the Powder River structural basin, a 


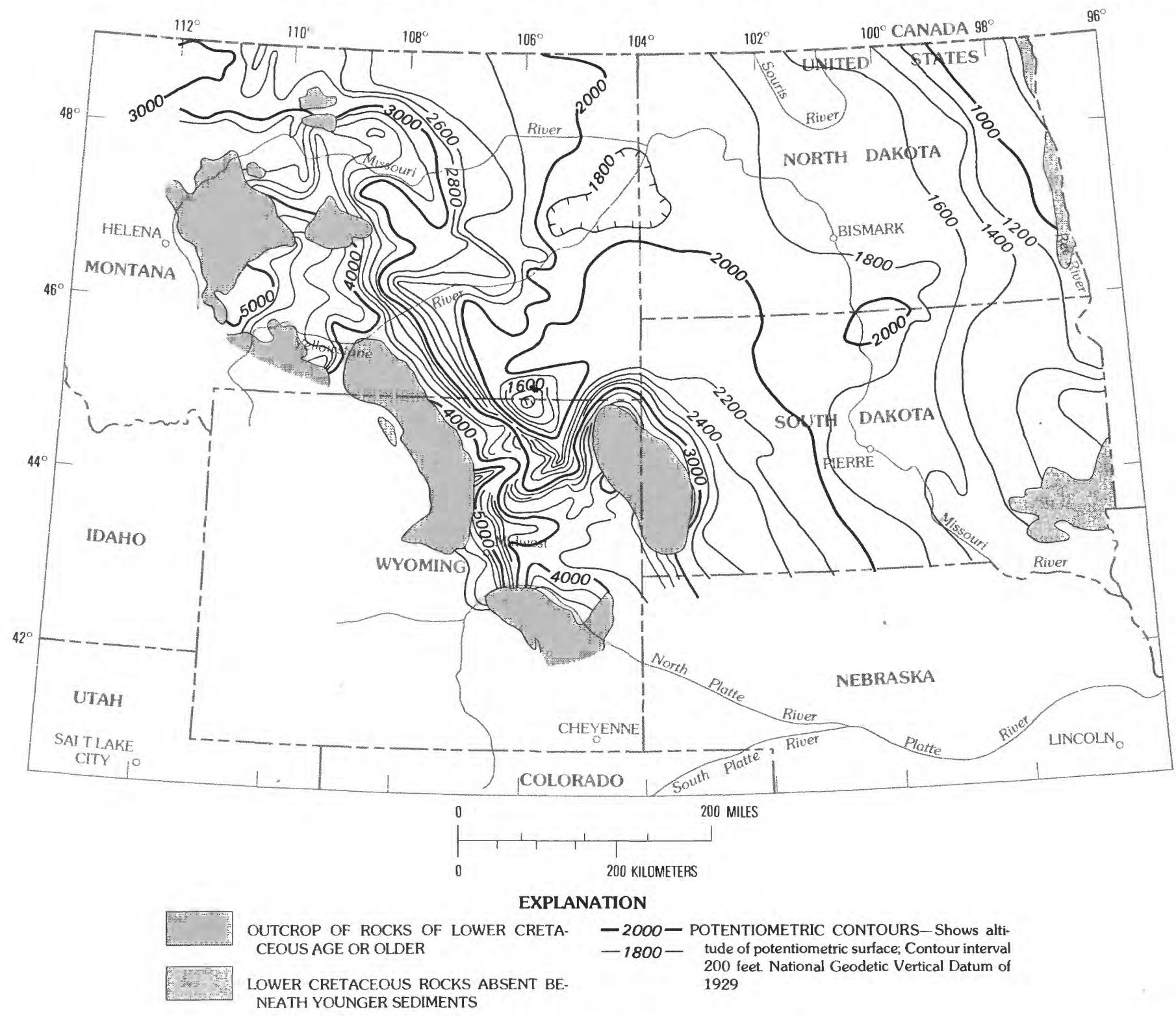

Figure 6.-Head in the Lower Cretaceous aquifer.

minor potentiometric depression in eastern Montana, and a southward extension of the low head area along the eastern flank of the Powder River basin may, in part, be the result of petroleum withdrawal. The potentiometric surface in eastern North Dakota and South Dakota has been lowered since 1900 by water wells completed in the aquifer in that area.

Although the potentiometric depression enclosed by the 1,000-ft contour as shown in figure 6 in the Lower Cretaceous aquifer of the Powder River structural basin may be, in part, due to petroleum withdrawal from the Muddy Sandstone, there is no clear indication of head decline with time. Some other explanation, such as reverse osmotic effects and (or) rapid unloading due to erosion, may be needed. The effects of the low heads within the potentiometric depression are not detectable outside of the depression; this may be due to the isolation of the sand bodies in the depression area from the regional system.

\section{GROUND-WATER TEMPERATURES}

Measurements of bottom-hole temperatures in oilproducing areas, and water temperatures in areas where the Dakota Sandstone or equivalent is used for domestic, stock, and municipal water supplies give a reasonable temperature distribution in the Lower Cretaceous aquifer (fig. 7). Highest temperatures are in the southwestern 


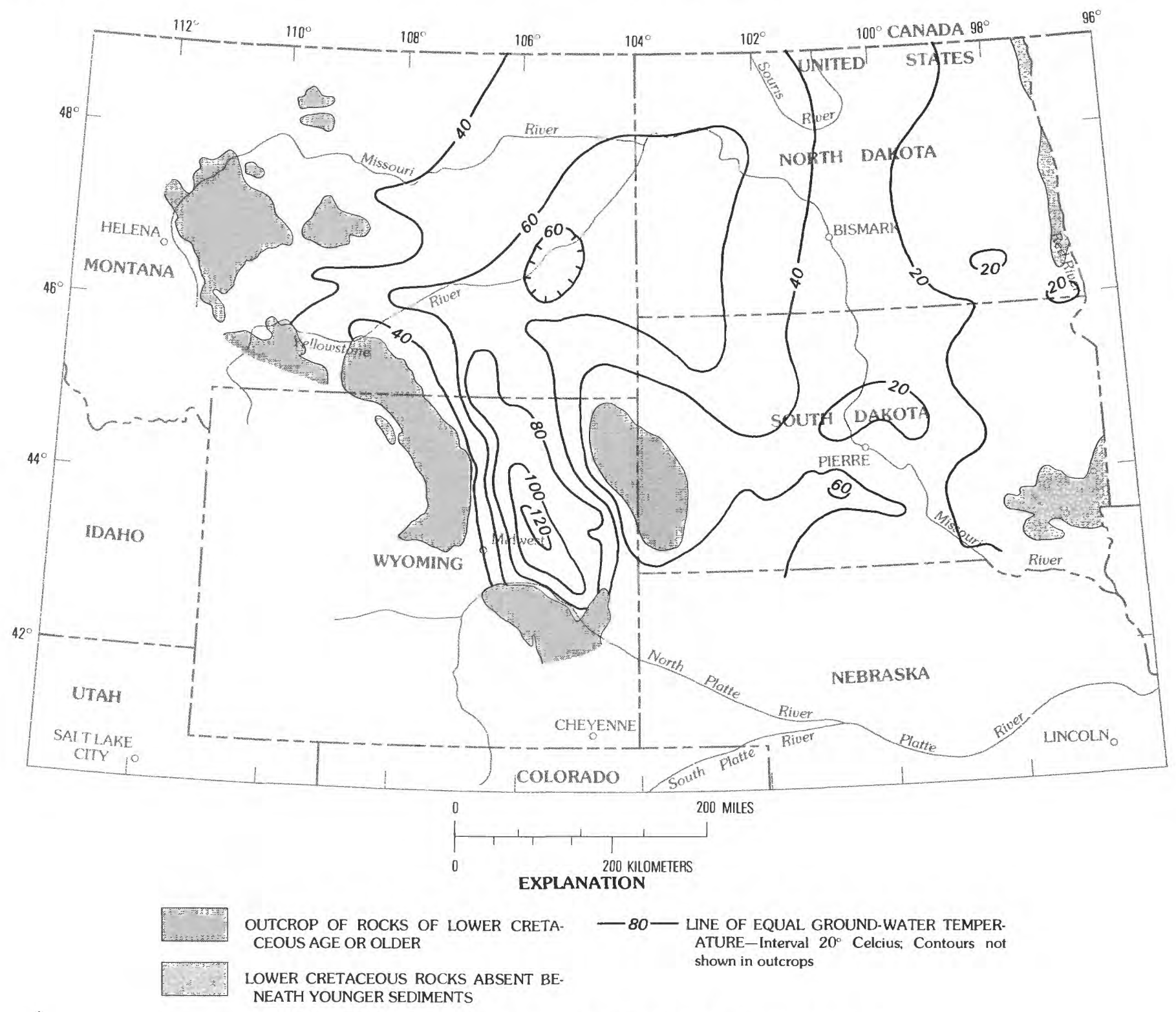

FIGURE 7.-Water temperatures in the Lower Cretaceous aquifer.

Powder River basin, where temperatures as high as $128^{\circ} \mathrm{C}$ are found at a depth of about $13,000 \mathrm{ft}$. Lowest temperatures are less than $16^{\circ} \mathrm{C}$ in outcrop areas in westcentral Montana, in the Black Hills area in northwestern South Dakota and northeastern Wyoming, and in the eastern part of North Dakota and South Dakota, where the aquifer is less than $1,600 \mathrm{ft}$ below land surface. Most of the area has a geothermal gradient of about $1^{\circ} \mathrm{C}$ per $108 \mathrm{ft}$ of depth. Exceptions are those areas with a significant vertical hydraulic gradient, such as the highrelief areas of central Montana and near the central North Dakota-South Dakota border, where warmer water from the Paleozoic formations appears to be moving upward. Some individual wells show a geothermal gradient of slightly more than $1^{\circ} \mathrm{C}$ per $90 \mathrm{ft}$ of depth. Higher temperatures $\left(25^{\circ} \mathrm{C}\right.$ or more $)$ seem to be localized at individual wells.

\section{SUMMARY AND CONCLUSIONS}

Comparison of shut-in pressures, fluid recovery, and bottom-hole temperatures from several drill-stem tests shows that low heads and low temperatures are always associated with the fluid recovery. The converse also is true.

Highest heads and highest temperatures seem to be located along minor structural trends. Minor structural trends may have controlled deposition of sand or the 
location of fractures and probably the porosity. The heads and temperatures determined by drill-stem tests at test holes yielding high fluid recoveries may more closely reflect the formation temperatures and heads than those determined from drill-stem tests in test holes yielding low fluid recoveries.

The potentiometric surfaces mapped for the Tertiary, Upper Cretaceous, and Lower Cretaceous aquifers have a general northward trend in the Powder River structural basin and a general eastward trend across the remainder of the area. The ground-water divide across the southern Powder River structural basin persists throughout the vertical section. This feature may be related to a very persistent structural arch of low relief.

Potentiometric surfaces of the Tertiary and Upper Cretaceous aquifers are similar. Although the general pattern is similar in the Powder River structural basin, the potentiometric surface is several hundred feet lower in the Upper Cretaceous aquifer than in the Tertiary aquifer, however.

\section{SELECTED REFERENCES}

Balster, C.A., 1971, Stratigraphic correlations for Montana and adjacent areas: Montana Bureau of Mines and Geology Special Publication 51, 1 chart.

Boggs, J.M., and Jenkins, A.M., 1980, Analysis of aquifer tests conducted at the proposed Burdock uranium mine site, Burdock, South Dakota: Tennessee Valley Authority, Office of Natural Resources, Division of Water Resources, Water System Development Branch Report no. WR28-1-520-109, $73 \mathrm{p}$.

Bredehoeft, J.D., Blyth, C.R., White, W.A., and Maxie, G.B., 1963, Possible mechanism for concentration of brines in subsurface formations: Bulletin of the American Association of Petroleum Geologists, v. 47, no. 2, p. 257-269.

Butler, R.D., 1975, Groundwater flow in Paleozoic and Mesozoic sediment in the Williston basin of North Dakota, Part IHydraulic potential and permeability from drill-stem test data: University of North Dakota, Geology Department, Progress Report, $58 \mathrm{p}$.

Clark, S.P., Jr., 1966, Handbook of physical constants (revised edition): Geological Society of America Memoir 97, $587 \mathrm{p}$

Earlougher, R.C., Jr., 1977, Advances in well test analysis: Dallas, Tex., Society of the Petroleum Engineers of the American Institute of Mining, Metallurgical, and Petroleum Engineers Monograph, v. 5, 264 p.

Gray, D.H., and Mitchell, J.K., 1967, Fundamental aspects of electro-osmosis in soils: Proceedings of the American Society of Civil Engineers, Journal of the Soil Mechanics and Foundations Division, v. 93, no. SM6, p. 209-236.

Grose, L.T., 1972, Tectonics, in Geologic atlas of the Rocky Mountain region: Denver, Colo., Rocky Mountain Association of Geologists, p. 35-44.

Imlay, R.W., 1980, Jurassic paleobiogeography of the conterminous United States in its continental setting: U.S. Geological Survey Professional Paper 1062, 134 p.

Lobmeyer, D.H., 1980, Preliminary potentiometric-surface map showing freshwater heads for the Lower Cretaceous rocks in the Northern Great Plains of Montana, North Dakota,
South Dakota, and Wyoming: U.S. Geological Survey OpenFile Report 80-757, scale 1:1,000,000.

Lobmeyer, D.H., Anna, L.O., and Busby, J.F., 1982, Preliminary data for Northern Great Plains test well 1, NW1/4 NE $1 / 4$ sec. 11., T. 55 N., R. 77 W., Sheridan County, Wyoming: U.S. Geological Survey Open-File Report 82-446, 72 p.

Lowry, M.E., 1981, The relative importance of regional and local ground-water systems in the Powder River structural basin, Wyoming and Montana [abs.]: Annual Rocky Mountain Groundwater Conference, 10th, Laramie, Wyo., 1981, Proceedings, p. 71 .

Maier, L.F., and Ripley, H.E., 1967, Formation evaluation by drill stem testing: Ontario Petroleum Institute Conference, 6th, London, Ontario, 1967, Proceedings, 32 p.

Miller, W.R., 1976, Water in carbonate rocks of the Madison group in southwestern Montana-A preliminary evaluation: U.S. Geological Survey Water-Supply Paper 2043, 51 p.

Olsen, H.W., 1969, Simultaneous fluxes of liquid and charge in saturated kaolinite: Soil Science Society of America Proceedings, v. 33 , no. 3 , p. $338-344$.

Potter, R.W., II, and Brown, D.L., 1977, The volumetric properties of aqueous sodium chloride solutions from $0^{\circ}$ to $500^{\circ} \mathrm{C}$ at pressures up to 2000 bars based on a regression of available data in the literature: U.S. Geological Survey Bulletin 1421-C, 36 p.

Rice, D.D., 1976, Correlation chart of Cretaceous and Paleocene rocks of the Northern Great Plains: U.S. Geological Survey Oil and Gas Investigations Chart OC-70.

Schoon, R.A., 1971, Geology and hydrology of the Dakota Formation in South Dakota: South Dakota State Geological Survey Report of Investigations 104, $55 \mathrm{p}$.

Skrivan, J.A., and Karlinger, M.R., 1980, Semivariogram estimation and universal Kriging program: U.S. Geological Survey Computer Contribution, Program K609, 98 p.

Slack, P.B. 1981, Paleotectonics and hydrocarbon accumulation, Powder River basin, Wyoming: Bulletin of the American Association of Petroleum Geologists, v. 65, no. 4, p. 730-743.

Stone, D.S., 1971, Tectonic sketch map of the central Rocky Mountains: Wyoming Geological Association Annual Field Conference, 23d, Cheyenne, Wyo., 1971, Guidebook, scale 1 inch $=30$ miles.

Swenson, F.A., 1968, New theory of recharge to the artesian basin of the Dakotas: Geological Society of America Bulletin, v. 79, no. 1 , p. $163-182$.

Tokarsky, O., 1974, Hydrological map, Lethbridge-Fernie, Alberta: Alberta Research Hydrological Map Series, accompanies Earth Sciences Report 74-1, scale 1:250,000.

Weast, R.C., ed., 1979, Chemical Rubber Company Handbook of Chemistry and Physics (59th ed., 1978--79): West Palm Beach, Fla., Chemical Rubber Company Press, Inc., 2,488 p.

Whitaker, S.H., 1967, Geology and groundwater resources of the Wood Mountain area (72-G), Saskatchewan: Saskatchewan Research Council Geology Division Map 5, scale 1:250,000. 1970, Geology and groundwater resources of the Swift Current area (72-J), Saskatchewan: Saskatchewan Research Council Geology Division Map, scale 1:250,000.

$1974 \mathrm{a}$, Geology and groundwater resources of the Willow Bunch area (72-H), Saskatchewan: Saskatchewan Research Council Geology Division Map 20, scale 1:250,000.

$1974 \mathrm{~b}$, Geology and groundwater resources of the Weyburn area (62-E, -F), Saskatchewan: Saskatchewan Research Council Geology Division Map 21, scale 1:250,000.

1976, Geology and groundwater resources of the Cypress area (72-F), Saskatchewan: Saskatchewan Research Council Geology Division Map 22, scale 1:250,000. 